\title{
The Method for Selecting Basophils Might Be Determinant in the Basophil Activation Test in Patients With Mastocytosis
}

Urra $\mathrm{JM}^{1,3}$, Pérez-Lucendo $\mathrm{I}^{1}$, Extremera $\mathrm{A}^{2}$, Feo-Brito $\mathrm{F}^{2,3}$, Alfaya $\mathrm{T}^{2}$

${ }^{1}$ Immunology Unit, Hospital General Universitario de Ciudad Real, Facultad de Medicina de Ciudad Real, Ciudad Real, Spain ${ }^{2}$ Allergy Unit, Hospital General Universitario de Ciudad Real, Facultad de Medicina de Ciudad Real, Ciudad Real, Spain ${ }^{3}$ Universidad de Castilla La Mancha, Ciudad Real, Spain

J Investig Allergol Clin Immunol 2020; Vol. 30(1): 65-67 doi: 10.18176/jiaci.0442

Key words: Hymenoptera venom allergy. Mastocytosis. Basophil activation test. IgE. CCR3.

Palabras clave: Alergia a veneno de himenópteros. Mastocitosis. Test de activación de basófilos. IgE. CCR3.

Mastocytosis is a heterogeneous disorder characterized by the proliferation and accumulation of mast cells (MCs) in the skin, bone marrow, and other tissues [1]. Owing to massive MC activation and release of mediators, patients with mastocytosis may experience systemic symptoms, including hypotension and shock, flushing, headache, abdominal pain, and diarrhea. Serum baseline tryptase correlates with the total MC count and burden and is increased in many patients. In mastocytosis, MC can be activated by various stimuli, including hymenoptera venom, through an IgE-mediated mechanism [2]. There are several reports on patients with systemic mastocytosis (SM) and a history of severe sting reactions, but with negative venom-specific $\operatorname{IgE}$ and skin test results [3]. In such cases, other diagnostic methods, such as the basophil activation test (BAT), can prove useful [4]. Reports about the usefulness of BAT in patients with negative specific IgE (sIgE) results show varying results. Some studies find that BAT does not provide useful information in this kind of patient $[5,6]$, while other papers report the opposite $[7,8]$. Interestingly, different methods for identifying basophils were used in the studies, and negative results were obtained in those using chemokine CC receptor type 3 (CCR3) [5,6], whereas positive results were obtained in those using the IL3 receptor (CD123) in conjunction with HLA-DR [7] or CD45 and IgE [8].

We discuss the usefulness of BAT in 2 patients with systemic reactions after wasp sting and mastocytosis.

We studied 2 men aged 53 and 64 years (patient 1 and patient 2 , respectively) with systemic reactions after wasp sting. Patient 1 presented dizziness, vomiting, dyspnea, and loss of consciousness 25 minutes after the sting, and patient 2 experienced flushing and loss of consciousness 10 minutes after the sting. Neither experienced cutaneous symptoms. Both had high tryptase values $(>20 \mu \mathrm{g} / \mathrm{mL})$ (Table) 1 month after the reactions. 
Table. Results of slgE and BAT. Results of BAT Using IgE or CCR3 for the Selection of Basophils in the Assay in Patient 1

\begin{tabular}{|c|c|c|}
\hline & Patient 1 & Patient 2 \\
\hline Total IgE & $8.06 \mathrm{kU} / \mathrm{L}$ & $27.9 \mathrm{kU} / \mathrm{L}$ \\
\hline sIgE Vespula species & $<0.01 \mathrm{kU} / \mathrm{L}$ & $0.08 \mathrm{kU} / \mathrm{L}$ \\
\hline sIgE Polistes dominula & $0.08 \mathrm{kU} / \mathrm{L}$ & $0.09 \mathrm{kU} / \mathrm{L}$ \\
\hline sIgE Bombus terrestris & $<0.1 \mathrm{kU} / \mathrm{L}$ & ND \\
\hline sIgE Apis mellifera & $<0.01 \mathrm{kU} / \mathrm{L}$ & $0.01 \mathrm{kU} / \mathrm{L}$ \\
\hline r Ves v 1 & $0.01 \mathrm{kU} / \mathrm{L}$ & $0.02 \mathrm{kU} / \mathrm{L}$ \\
\hline r Ves v 5 & $<0.01 \mathrm{kU} / \mathrm{L}$ & $0.01 \mathrm{kU} / \mathrm{L}$ \\
\hline r Pol d 5 & $0.05 \mathrm{kU} / \mathrm{L}$ & $<0.01$ \\
\hline r Api m 1 & $<0.1 \mathrm{kU} / \mathrm{L}$ & ND \\
\hline Intradermal tests & Negative & ND \\
\hline Basal serum tryptase & $40.5 \mu \mathrm{g} / \mathrm{L}$ & $23.2 \mu \mathrm{g} / \mathrm{L}$ \\
\hline BAT & & \\
\hline Method for basophil selection & $\operatorname{IgE}$ & $\operatorname{IgE}$ \\
\hline BAT negative control & $3.5 \%$ & $3.0 \%$ \\
\hline BAT positive control (fMLP) & $67 \%$ & $64 \%$ \\
\hline BAT Polistes & $22 \%$ & $21 \%$ \\
\hline BAT Vespula & $41 \%$ & $30 \%$ \\
\hline BAT (6 mo later) & \\
\hline Method for basophil selection & \multicolumn{2}{|c|}{$\begin{array}{l}\text { Patient } 1 \\
\text { IgE } \quad \text { CCR3 }\end{array}$} \\
\hline BAT negative control & $4.3 \%$ & $3.7 \%$ \\
\hline BAT positive control (fMLP) & $53.5 \%$ & $51.2 \%$ \\
\hline BAT Polistes & $40.9 \%$ & $4.7 \%$ \\
\hline BAT Vespula & $79.9 \%$ & $19.3 \%$ \\
\hline
\end{tabular}

Abbreviations: BAT, basophil activation test; fMLP, formyl-methionylleucyl-phenylalanine; ND, not determined; sIGE, specific IgE.

Both patients had a Red Española de Mastocitosis (REMA [Spanish Network on Mastocytosis]) score >2 [9], which was suggestive of clonal mast cell disorder, and were diagnosed with indolent SM after bone marrow biopsy at Instituto de Estudios de Mastocitosis de Castilla La Mancha (CLMast) according to World Health Organization (WHO) criteria.

sIgE against whole venom and components was determined several months after the reaction. Intradermal tests (IDT) with Apis mellifera, Vespula species, and Polistes dominula venoms up to $1 \mu \mathrm{g} / \mathrm{mL}$ were also performed in patient 1 . The results of sIgE and IDT were negative (Table).

In order to determine sensitization to venom, BAT was performed as previously described [10]. Basophils were detected initially using an anti-IgE monoclonal antibody, and the degranulated basophils were detected by expression of CD63 on the surface of the cells. The test was carried out against venom from $P$ dominula and Vespula species at a final concentration of $1 \mu \mathrm{g} / \mathrm{mL}$ (Pharmalgen ALK-Abelló). BAT results were positive ( $>15 \%$ of activated basophils) in both patients for both venoms (Table), thus enabling identification of sensitization and prescription of venom immunotherapy.

In patient 1 , we repeated BAT 6 months later using 2 different membrane molecules (IgE and CCR3) to identify basophils. These tests were performed after 6 months of immunotherapy with Vespula and Polistes venoms. As shown in the table, positive results for Vespula and Polistes were obtained using $\mathrm{IgE}$, while a lower value for Vespula and a negative result for Polistes were obtained using the CCR3 molecule.

Both patients were diagnosed with SM, with an anaphylactic reaction after wasp sting and negative results in the classic diagnostic tests for hymenoptera venom allergy (HVA), and had a positive result in BAT against hymenoptera venom. In the absence of classic diagnostic tests, this cellular test showed that the reaction was mediated by IgE and thus enabled prescription of venom immunotherapy. Venom-specific IgE cannot be detected in 5\%-10\% of patients with mastocytosis and HVA [3], because of increased absorption of circulating IgE by the large amount of mast cells, with consequent low circulating levels of sIgE that prevent appropriate detection with classic tests. This may also be responsible for the negative results in the skin tests.

BAT is based on exposure of specific antigens against sIgE bound to FceRI receptors on the surface of basophils. Specific antigen-antibody binding induces degranulation of basophils, and constituent molecules in the membrane of basophil granules such as CD63 or CD203 are expressed in the cell membrane and can be detected by the antibodies used in the test. The large number of mast cells present in patients with SM can reduce the presence of $\mathrm{IgE}$ in the membrane of basophils. In fact, BAT has shown good results in patients with HVA without mastocytosis under the same conditions and with the same dose of allergen [10]. Various flow cytometry-based methods can be used to identify basophils in whole blood (eg, IgE, CCR3, CD203c/CD123/HLA-DR, and CD45/CD123/HLA-DR). Interestingly, in the studies that show little or no validity for the BAT assay in patients with SM and negative sIgE, basophils are recognized by means of the eotaxin-3 receptor (CCR3) [5,6]. In this case, it is probably basophils with low amounts of $\operatorname{IgE}$ on their surface that are selected, thus explaining the poor results of the BAT. Under this assumption, detecting basophils in BAT with an anti$\mathrm{IgE}$ antibody would clearly improve the results and make it possible to avoid false negatives. In our study, a sample was tested in parallel using IgE and CCR3 to identify basophils, and we found lower values using CCR3. Even with Polistes, the results changed from positive to negative $(<5 \%)$ when basophils were identified by CCR3. The patient was receiving venom immunotherapy when these second BATs were performed, although this did not influence the results, as the tests were performed in parallel, with the same blood sample, and at the same time. Adequate selection of the molecule used for the identification of basophils in BAT could ensure optimal results in patients with SM and HVA. Under these premises, BAT may be an adequate tool for assessing patients with SM and systemic reactions due to hymenoptera venom.

\section{Funding}

This study was supported by Instituto de Salud Carlos III (ISCIII) and cofunded by Fondo Europeo de Desarrollo Regional (FEDER) for the Thematic Networks and Cooperative Research Centres: ARADyAL (RD16/0006/0028).

\section{Conflicts of Interest}

The authors declare that they have no conflicts of interest. 


\section{References}

1. Theoharides TC, Valent P, Akin C. Mast Cells, Mastocytosis, and Related Disorders. N Engl J Med. 2015;373(19):1885-6.

2. Vázquez-Revuelta $P$, González-de-Olano D. Prevalence of Clonal Mast Cell Disorders in Patients Presenting With Hymenoptera Venom Anaphylaxis Might Be Higher Than Expected. J Invest Allergol Clin Immunol. 2018;28(3):193-4.

3. Golden DB, Tracy JM, Freeman TM, Hoffman DR. Negative venom skin test results in patients with histories of systemic reaction to a sting. J Allergy Clin Immunol. 2003;112:495-8.

4. Alfaya Arias T, Soriano Gómis V, Soto Mera T, Vega Castro A, Vega Gutiérrez JM, Alonso Llamazares A, et al. Key Issues in Hymenoptera Venom Allergy: An Update. J Invest Allergol Clin Immunol. 2017;27(1):19-31.

5. Rietveld MJA, Schreurs MWJ, Gerth van Wijk R, van Daele PLA, Hermans MAW. The Basophil Activation Test Is Not a Useful Screening Tool for Hymenoptera Venom-Related Anaphylaxis in Patients with Systemic Mastocytosis. Int Arch Allergy Immunol. 2016;169:125-9.

6. Bonadonna P, Zanotti R, Melioli G, Antonini F, Romano I, Lenzi $L$, et al. The role of basophil activation test in special populations with mastocytosis and reactions to hymenoptera sting. Allergy. 2012;67:962-5.

7. Korošec P, Šilar M, Eržen R, Čelesnik N, Bajrović N, Zidarn M, et al. Clinical routine utility of basophil activation testing for diagnosis of hymenoptera-allergic patients with emphasis on individuals with negative venom-specific $\lg E$ antibodies. Int Arch Allergy Immunol. 2013;161:363-8.

8. Bidad K, Nawijn MC, van Oosterhout AJM, van der Heide $S$, Oude Elberink JNG. Basophil activation test in the diagnosis and monitoring of mastocytosis patients with wasp venom allergy on immunotherapy. Cytometry B Clin Cytom. 2014;86:183-90.

9. Alvarez-Twose I, González-de-Olano D, Sánchez-Muñoz L, Matito A, Jara-Acevedo M, Teodosio C, et al. Validation of the REMA score for predicting mast cell clonality and systemic mastocytosis in patients with systemic mast cell activation symptoms. Int Arch Allergy Immunol. 2012;157:275-80.

10. Urra JM, Cabrera CM, Alfaya T, Feo-Brito F. Agreement of skin test with IL-4 production and CD40L expression by T cells upon immunotherapy of subjects with systemic reactions to Hymenoptera stings. Mol Immunol. 2016;70:134-9.

- Manuscript received May 7, 2019; accepted for publication August 16, 2019.

Teresa Alfaya

Alergología

Hospital General Universitario de Ciudad Real 13005 Ciudad Real, Spain

E-mail: talfaya@sescam.jccm.es 